\title{
OS POVOS INDÍGENAS E AS EMPRESAS: REFLEXO DE UMA POLÍTICA SELETIVA E ANTIDEMOCRÁTICA
}

\section{FABIANA CARICATI}

Advogada. Mestranda do Programa de Pós-Graduação Strictu Sensu em Direito Empresarial e Cidadania no Centro Universitário Curitiba - Unicuritiba, Paraná. Email: fabiana@caricati.adv.br

GABRIELLA DE PAULA

Graduanda em Direito pela PUC-Paraná. Email: gabriella@caricati.adv.br.

\section{RESUMO}

De acordo como Censo do IBGE (Instituto Brasileiro de Geografia e Estatísticas), o Brasil é um país onde vivem aproximadamente 900 mil indígenas. Encontram-se divididos em 305 diferentes etnias, falantes de 274 línguas e presentes em todas as regiões do país. Segundo o mesmo Censo, o País tem 505 terras indígenas (Tl's), que representam $12,5 \%$ do território brasileiro (106,7 milhões de hectares), onde residem 517,4 mil indígenas $(57,7 \%)$, dos quais 251,9 mil $(48,7 \%)$ estão na região Norte. Excetuando o povo Tikuna, que é a maior etnia indígena, com 46.045 indivíduos declarados, a segunda e a terceira maiores etnias, que são Guarani e Kaiowá (43.401 indivíduos) e Kaingang (37.470 indivíduos), vivem ao sul do país, fora da Amazônia. (BRAGATTO, 2019). Apesar das graves violências a que estão constantemente submetidos, devemos considerar que há um corolário de direitos já assegurados. No que diz respeito aos direitos destes povos, hodiernamente há um novo paradigma de reconhecimento da pluralidade étnica a ser considerado e que está amparado por diversas legislações, normas administrativas, tratados, acordos, declarações e convenções, ratificados pelo 
Personalidade Acadêmica Homenageada:

Raymundo Juliano Feitosa (Universidade Federal do Rio Grande do Norte - UFRN)

Estado brasileiro. Também a Constituição Federal de 1988 reconheceu, por diversos de seus dispositivos, o caráter multiétnico da sociedade brasileira e os direitos de coletividades culturalmente diferenciadas, em especial dos povos indígenas. São direitos que não podem ser desconsiderados, haja vista que foram transformados em matéria de ação administrativa para os gestores políticos e públicos brasileiros. Não se trata de mera liberalidade dos poderes da República acatarem ou não tais disposições, pois, já foram reconhecidas pelo Estado brasileiro. Ressalta-se o compromisso nacional e internacional no tocante a temática; quanto ao compromisso nacional, destaca-se o Programa Nacional de Direitos Humanos (PNDH-3), instituído pelo Decreto n. 7.037, de 21/12/2009 e atualizado pelo Decreto n. 7.177 , de 12/05/2010, o qual abrange direitos humanos e responsabilidades empresariais, e o Decreto no 9.571, de 22 de novembro de 2018, que estabelece as Diretrizes Nacionais sobre Empresas e Direitos Humanos para médias e grandes empresas, incluídas as empresas multinacionais com atividades no país. Diante destas considerações, compreende-se que o estudo deste tema é de fundamental importância face aos novos desafios propostos à sociedade contemporânea, com novas demandas, com vistas à interculturalidade, e, com um perfil inovador, ancorado no direito dos povos indígenas tal qual propõe a Magna Carta brasileira, bem como os demais acordos, convenções e tratados internacionais dos quais o Brasil é signatário. Por outro lado, as empresas envolvidas devem se comprometer publicamente a respeitar, em suas atividades, todos os padrões internacionais de direitos humanos, de acordo com os padrões estabelecidos nas Diretrizes das Nações Unidas sobre Empresas e Direitos Humanos. Mas grandes projetos de desenvolvimento e a expansão de atividades agrícolas e extrativas constituem, hoje, uma grande ameaça aos povos indígenas.

PALAVRAS-CHAVE: Direitos humanos; Internacional; Indígenas; Empresas; Sociedade. 
Personalidade Acadêmica Homenageada:

Raymundo Juliano Feitosa (Universidade Federal do Rio Grande do Norte - UFRN)

\section{REFERÊNCIAS}

ARAÚJO, Ana Valéria et alii. Povos Indígenas e a "Lei dos Brancos": o direito à diferença. Vol. 3. Brasília, MEC/SECAD; LACED/Museu Nacional. Disponível em http://www.laced.mn.ufrj.br/trilhas/. 2006.

BRAGATO, Fernanda, F. Os Caminhos do Genocídio Indígena na atual Política Brasileira. disponível em: <https://emporiododireito.com.br/leitura/os-caminhos-dogenocidio-indigena-na-atual-politica-brasileira> . Acesso em : 01 de maio de 2019.

CARDOSO DE OLIVEIRA, Luís Roberto. Direitos Culturalmente Diferenciados, Antropologia e Ética. Revista Brasileira de Antropologia. ABA, acesso em 20 de abril de 2018.

CIMI. Relatório Violência contra os Povos Indígenas do Brasil. Brasília, DF, 2018.

COMISSIÓN INTERAMERICANA DE DERECHOS HUMANOS (CIDH). "Relatório sobre os Direitos dos povos indígenas e tribais sobre suas terras ancestrais e recursos naturais: normas e jurisprudência do sistema interamericano de direitos humanos". OEA/Ser.L/V/II. Doc. 56/09, 2010

CONVENÇÃO 169 DA OIT sobre povos indígenas e tribais: oportunidades e desafios para sua implementação no Brasil / (organizadora Biviany Garzón). São Paulo: Instituto Socioambiental, 2009.

FOUCAULT, Michel. A Ordem do Discurso. São Paulo: Loyola, 1996

FANON, Frantz. Pele negra máscaras brancas. Título original: "Peau noire, masques blancs". Salvador: EDUFBA, 2008.

GONZÁLEZ Casanova. Pablo. Colonialismo interno. [Unaredefinición]. En A. Borón, J. Amadeo y S. González, comps. La teoría marxista hoy. Problemas y perspectivas. Argentina: CLACSO, 2006.

IBGE. Atlas Nacional Digital do Brasil 2016. Disponível em: <http://www.ibge.gov.br/apps/atlas_nacional/>. Acesso em: 01 maio 2019.

LAS CASAS, Bartolomé de. 0 paraíso destruído: brevíssima relação da destruição das Índias. 6ª ed. Porto Alegre: L\&PM, 1996.

NAÇÕES UNIDAS. Los pueblos indígenas en América Latina: Avances en el último decênio y retos pendientes para la garantía de sus derechos. Santiago de Chile: Nações Unidas / CEPAL, 2014 
Personalidade Acadêmica Homenageada:

Raymundo Juliano Feitosa (Universidade Federal do Rio Grande do Norte - UFRN)

PALUMA Thiago, ÁLVAREZ ROSERO Luis Carlos. El derecho y multiculturalismo: los estados y su reconocimiento constitucional a grupos sociales indigenas en latinoamerica en garantia de sus derechos fundamentales. Revista Jurídica UNICURITIBA. Disponível em: <http://revista.unicuritiba.edu.br/index.php/RevJur/article/view/3209/371371726> Acesso em: 01 de maio de 2019.

QUIJANO, Aníbal. Colonialidade do poder, eurocentrismo e América Latina. In: LANDER, Edgardo (Org.). A colonialidade do saber: eurocentrismo e ciências sociais. Perspectivas latino-americanas. Buenos Aires: CLACSO, 2005.

Colonialidade do Poder e Classificação Social. In: SANTOS, Boaventura de Sousa; MENESES, Maria Paula (Org.). Epistemologias do Sul. Coimbra: Edições Almedina, 2009.

SOUZA FILHO, Carlos Frederico Marés de. Textos clássicos sobre os direitos e os povos indígenas. Curitiba: Juruá/NDI, 1992.

- Carlos Frederico Marés de. 0 renascer dos povos indígenas para o Direito. Curitiba: Juruá, 1999.

WOLKMER, Antônio Carlos.; LEITE, J. R. M. (orgs). Introdução aos Fundamentos de uma teoria geral dos "novos" direitos. In: Os "novos" direitos no Brasil: natureza e perspectivas: uma visão básica das novas conflituosidades jurídicas. São Paulo: Saraiva, 2011. 